\title{
Support from teachers and trainers in Vocational education and training: The pathways to career aspirations and further career development
}

\author{
Claudia Hofmann* \\ University of Applied Science in Special Needs Education \\ Schaffhauserstr. 239, 8050 Zurich, Switzerland \\ E-mail: claudia.hofmann@hfh.ch \\ Barbara E. Stalder \\ University of Teacher Education, \\ Institute of Upper Secondary Education \\ Fabrikstr. 8, 3012 Bern, Switzerland \\ E-mail: barbara.stalder@phbern.ch

\section{Franziska Tschan} \\ University of Neuchâtel, \\ Institute for Work and Organizational Psychology \\ Emile Argand 11, 2009 Neuchâtel, Switzerland \\ E-mail: franziska.tschan@unine.ch

\section{Kurt Häfeli} \\ University of Applied Science in Special Needs Education \\ Schaffhauserstr. 239, 8050 Zurich, Switzerland \\ E-mail: kurt.häfeli@hfh.ch \\ * Corresponding author
}

\begin{abstract}
Transition from school to work is a challenging period for young people with learning difficulties. In the dual vocational system of Switzerland, teachers at vocational educational and training (VET)-schools, as well as trainers at VETcompanies, provide important support. We were interested in the different pathways from this support to apprentice's career aspirations and further training. Structural equation modelling was used to analyse data from a longitudinal study in four occupational sectors. Results show that VET-teacher support is directly and indirectly related to career aspirations at the end of the apprenticeship, whereas VET-trainer support influences career aspirations only indirectly. Domain specific constructs (ability self-concept at VET-school, skill variety at the VET-company) and self-esteem are important as intermediary variables. Ability self-concept at VET-school had a strong influence on further education three years after the apprenticeship.
\end{abstract}


Keywords: School-to-work transition, special educational needs, learning difficulties, social support, vocational education and training, longitudinal study

\section{Bibliographical notes:}

Claudia Hofmann, lic.phil. is a research associate at the University of Applied Science in Special Needs Education in Zurich, Switzerland. Her research interests focus on school-to-work transition and assessment in the working life of young people with disabilities.

Barbara Stalder, $\mathrm{PhD}$ is a professor at the University of Teacher Education of Bern and associate professor at the University of Neuchâtel. Her research interests focus on school-to-work transitions and career development in young adulthood.

Franziska Tschan, $\mathrm{PhD}$ is a full professor of Social Psychology at Work at the University of Neuchâtel, Switzerland. Her research interests are interactions at work and teamwork.

Kurt Häfeli, Dr. phil. is a professor at the University of Applied Sciences in Special Needs Education in Zurich, Switzerland. His research interests are school-to-work transitions and professional development over the lifespan. 


\section{Introduction}

The transition from school to work is one of the major developmental tasks for young adults; it also has important consequences for further career development (Grob and Jaschinski, 2003; Nurmi, Salmela-Aro and Koivisto, 2002). The Swiss educational policy states that by $2015,95 \%$ of all young adults should complete a post-compulsory education qualification at the upper secondary level. With $93 \%$ in 2011, this target has almost been met ${ }^{1}$.

A successful transition from school to work is a particular challenge for young people with learning difficulties, because they may face difficulties finding a suitable apprenticeship, fulfilling requirements at the vocational education and training (VET)-school and as finding employment after the apprenticeship (Felkendorf and Lischer, 2005; Häfeli and Schellenberg, 2009; Heinz, 2002; Hupka, Sacchi and Stalder, 2006; Neuenschwander and Grunder, 2010; OECD, 2000). It is therefore important to study factors that facilitate transition from school to work for this population.

In 2004, Switzerland introduced an adapted training program as part of the dual system to help young adults with learning difficulties to complete a postcompulsory qualification (Kammermann, 2010; Kammermann, Amos, Hofmann and Hättich, 2009; Kammermann, Stalder and Hättich, 2011). This two-year program for young people with more practical skills combines part-time classroom instructions with part-time apprenticeship in a VET-company as regular VETprograms do (Stalder and Nägele, 2011). In addition, apprentices are eligible for additional support from VET-schools, and VET-schools and VET-companies cooperate closely. Additional support includes learning support and support if personal problems or conflicts in the VET-company arise. A goal of this training program is to assure successful graduation - apprentices obtain a recognised qualification for a specific occupational profile. Specific goals of this program are to increase employability and also permeability for further training and career development (e.g. the Federal VET diploma).

It is generally assumed that career-related social support (i.e., advice, emotional support or instrumental help) is important for young adults that have to cope with the demands of a transition at work. Career-related social support improves self-regulation capacities and lowers career concerns (Creed, Fallon and Hood, 2009). Career-related social support helps apprentices to develop competences (Neuenschwander, Frey and Gasser, 2007), increase persistence (Hackett, Betz, Casas and Rocha-Singh, 1992), enhance perceived abilities (Rice, Barth, Guadagno, Smith and McCallum, 2013) and increase performance (Day and Allen, 2004). It thus leads to more positive career outcomes. Although the effects of career-related social support have been demonstrated for a general population, the question remains how social support at school or at work during apprenticeship influences career development and career success in a population with learning difficulties.

The general aim of this study is to better understand - for apprentices participating in the above mentioned adapted two-year program - how support provided by VET-teachers and by VET-trainers influences short- and long-term career aspirations. We define career aspirations as (positive) thoughts about the

Compared to the $82.2 \%$ average of Organisation for Economic Co-operation and Development (OECD) members, this rate is high (OECD 2013). 
future self in work environments or career situations. Career aspirations are important concepts in view of an ambitious career goal, because career aspirations focus one's resources on a particular task (Nurmi et al., 2002) and motivate behaviours related to the realization of preferred outcomes (Abele and Spurk, 2009; Beal and Crocket, 2010; Lent, Brown and Hackett, 2000). This is especially important for young people with learning difficulties, because they are more likely to encounter barriers, and thus have to make a greater effort to achieve professional goals.

More specifically, we contend that the two VET-learning environments in the dual system (VET-school and VET-company), each have specific demands, but also offer specific support (Thoits, 2011). We thus assume that the support given by VET-teachers at school and VET-trainers in the company influence career aspirations and career development through different intermediary paths: At VETschool, teachers provide support by supervising, encouraging and guiding the learning process. This likely helps to enhance the apprentice's school-related ability self-concept. At the VET-company, priorities are different: Apprentices develop competences based on work experiences, apply their competences and learn by doing. We thus expect that VET-trainers support apprentices by (inter alia) assigning them appropriate and varying tasks. In line with other studies (e.g., Linneham 2003), we further expect that self-esteem is an important link between experienced support, career aspirations and further education.

\section{Theoretical background}

\subsection{Social support, intermediary paths and career aspirations}

Social support is defined as 'a flow of emotional concern, instrumental aid, information, and/or appraisal between people' (House, 1981, p. 26) and is supposed to be helpful by satisfying senses of belonging, building up individual patterns of orientation and action to cope in a complex environment and by 'buffering' the negative effects of stress on well-being and mental health (Cohen and Wills, 1985; House, 1981; Laireiter, 1993), on work-related outcomes, e.g. work-satisfaction (e.g., Harris, 2007) or educational attainment (e.g., Diemer, 2007).

VET-situations typically evoke needs on different support dimensions: (i) emotional support (e.g., expressing esteem, providing comfort and encouragement after setbacks) (ii) cognitive/informational support (e.g., providing career-specific information, giving advice), and (iii) instrumental/behavioural support (e.g., active coping assistance, supervising and assigning tasks). Supervisors are important as supporters because they have experience with similar situations (Thoits, 2011).

Support is most effective when there is a 'triple match' between demands, resources (e.g., support) and individual outcome, meaning that qualitatively similar dimensions are affected (Chrisopoulos, Dollard, Winefield and Dormann, 2010). This means for example that an apprentice who is confronted with an emotionally demanding situation can be helped most effectively by emotional support to prevent a negative emotional reaction (e.g., getting depressed).

In the current study, the apprentices with learning difficulties have two supervisors that are potential sources of social support: Teachers at VET-school and trainers at the VET-company. As VET-teachers and VET-trainers represent different systems with specific demands, conditions and limitations (Lent et al., 
2000; Neuenschwander, Gerber, Frank and Rottermann, 2012), we expect - beside some similarities in the support provided - differences in the support provided:

(1) As for the similarities, VET-teachers and VET-trainers may both be an important source of emotional support. Emotional support of both supervisors may influence self-evaluations and self-esteem. Acceptance by supervisors influences self-esteem of subordinates (Day and Allen, 2004); supervisor support indicates to employees that they are valued and have career potential, which elicits positive affective reactions (Ng, Eby, Sorensen and Feldman, 2005). It has also been shown that support during apprenticeship (i.a., from supervisors, teachers but also from parents) leads to higher self-esteem (Linnehan, 2003; Vignoli, 2009), less selfdevaluation (Neuenschwander et al., 2007) and fewer career concerns (Creed et al., 2009). Self-esteem in turn might have consequences on other relevant dimensions such as career aspirations (see Nurmi et al., 2002).

However, there are also differences between support received at school and at work.

(2) At VET-school, the requirements challenge the apprentices with learning difficulties mainly on the cognitive dimension. We suppose that VET-teachers can help to (re)interpret school success/failure experiences. In doing this, they may influence the apprentice's view of his/her abilities at school and thus, their long term career aspirations. Social cognitive career theorists argue that social support influences outcomes such as career choices directly, but also indirectly via learning experiences and self-efficacy beliefs (Lent et al., 2000). Some studies found direct effects of school support on career aspirations and development (e.g., Diemer, 2007), but most empirical studies supported models with self-efficacy as a mediator between support and outcomes (Lent et al., 2001; Lent et al., 2003; Linnehan, 2003; Pan, Sun and Hau Siu Chow, 2011; Pinquart, Juang and Silbereisen, 2003; Restubog, Florentino and Garcia, 2010). Furthermore, teacher support was found to influence perceived abilities at school (Rice et al., 2013).

In accordance with social cognitive career theory (Lent et al., 2000), we contend that in the VET-school context, the ability self-concept at school is an appropriate domain-specific analogue for self-efficacy. Ability self-concept at school is defined as the apprentice's conception of his/her own ability to learn and succeed at VET-school. We further argue that the ability self-concept at school shapes expectations about potential future vocational pathways (effort required, probability of success or failure). It is therefore an important influence on career aspirations at the end of the apprenticeship (see Nurmi et al., 2002).

Based on the above considerations, we formulate the following hypotheses for VET-teacher support:

VET-teacher support directly influences career aspirations at the end of the apprenticeship (t1) (H1a). We also expect that the influence of VET teacher support on 11 career aspirations is partially mediated by $t 1$ ability self-concept at VET-school and by $t 1$ self-esteem (H1b).

(3) In VET-companies, requirements differ from requirements at school. In a company, apprentices are part of a productive team and have to learn how to fulfil their tasks efficiently (Singer, Gerber and Neuenschwander, 2013). Apprentices are expected to slowly grow from the role of a novice into that of an expert worker (Stalder and Nägele, 2011). The VET-trainer at the company is an important source of support in this context. Compared to the VET-teacher, the VET-trainer support may be available more often, because apprentices in the two year program stay four days per week at the VET-company and one day at VET-school. 
We contend that an important source of instrumental support at a VETcompany is provided by assigning interesting and varying tasks (high skill variety) to the apprentices and thus creating situations at work where apprentices have to behave and act as professionals. As work in the company is less structured and regulated than learning in VET-school (Neuenschwander et al., 2012), different companies may offer different opportunities to learn on the job. Assigning tasks that require using high skill variety enhances motivation (Hackman, 1980) and encourages apprentices to develop and use different competences. Assigning motivating tasks signals appreciation (Semmer and Beehr, 2014) and indicates that a person is seen as capable and competent which increases self-efficacy (Day and Allen, 2004). High skill variety tasks have a positive influence on self-esteem (Beal and Crocket, 2010), increase intrinsic learning motivation (Berweger, Krattenmacher, Salzmann and Schönenberger, 2013) and are related with more satisfaction and successful transition to the labour market for apprentices, whereas skill variety at VET-school did not have that effect (Stalder, 2012).

Practical activities, the possibility to explore and skill variety are assumed to be especially important for apprentices with learning difficulties in their career choice (Schellenberg and Hofmann, 2013), as performance-related feedback in such situations (e.g., by VET-trainers in the company) leads to an adjustment of future expectations and in this way influences future-oriented cognitions respectively career aspirations (Beal and Crocket, 2010).

Based on the above considerations, we formulate the following hypotheses for VET-trainer support:

VET-trainer support influences $t 1$ career aspirations directly (H2a). We further expect that VET-trainer support influence on 11 career aspirations is partially mediated by $t 1$ skill variety at the VET-company and by $t 1$ self-esteem (H2b).

\subsection{Longitudinal effects of social support on later career development}

Many studies investigated support effects using cross-sectional research designs. There are some exceptions: Diemer (2007) examined the longitudinal impact of instrumental school support on vocational expectations two years later, but this effect turned out to be not significant. Another study (Restubog et al., 2010) found that students who received more counselling sessions at school had greater career self-efficacy and were more positive about their career decisions six months later. In addition, they less often changed their academic program 18 months later. Lent et al. (2003) found that support's influence on persistence was indirect via selfefficacy, interests and goals. In a meta-analysis ( $\mathrm{Ng}$ et al., 2005), supervisor support predicted later career success, whereby effect sizes for subjective success were generally stronger (average correlation $=.31$ ) than those for objective career success (.10 resp.13).

We are interested in investigating whether support during apprenticeship influences young adults to undertake efforts for further training. This is an important question, because an additional certificate (e.g., a federal VET diploma) is a better base for future career development than a certificate of the two-year VET-program. Career aspirations are assumed to be important in this situation, because, especially for young people with learning difficulties, it might not be very attractive from a short-term perspective to make the effort and bear the costs of longer training (Maier and Brunstein, 2001; Nurmi et al., 2002). Nevertheless, we suppose that the influence of previous support is limited and indirect if we consider 
more 'objective' measures of career success (as, e.g., undertaking further education or not).

Based on the above considerations, we formulate the following hypotheses for longitudinal effects of VET-support:

VET-teacher and VET-trainer support at $\mathrm{t} 1$ influences career aspirations at $\mathrm{t} 2$ (three years later) indirectly via $t 1$ career aspirations and $t 1$ and $t 2$ self-esteem (H3) and VET-trainer support at $\mathrm{t} 1$ influences career aspirations at $\mathrm{t} 2$ indirectly via $\mathrm{t} 1$ career aspirations and $\mathrm{t} 1$ and $\mathrm{t} 2$ self-esteem $(\mathrm{H} 4)$.

Effects of support from VET-teachers and VET-trainers on undertaking further education (vs. not) are indirect via $\mathrm{t} 1$ and $\mathrm{t} 2$ career aspirations (H5a). Furthermore, ability self-concept at VET-school at $\mathrm{t} 1$ is a predictor for undertaking further education (H5b).

\subsection{Model}

Fig. 1 summarises the different pathways from VET-teacher and VET-trainer support to $\mathrm{t} 1$ career aspirations and to $\mathrm{t} 2$ career aspiration and $\mathrm{t} 2$ undertaking further education. VET-teacher support is supposed to influence t1 career aspirations directly (H1a) and indirectly via t1 ability self-concept at school and self-esteem (H1b). VET-trainers support is supposed to influence tl career aspirations directly $(\mathrm{H} 2 \mathrm{a})$ and indirectly via skill-variety at the VET-company and self-esteem (H2b). We further hypothesise indirect longitudinal effects of VETteacher and VET-trainer support on $\mathrm{t} 2$ career aspirations via $\mathrm{t} 1$ career aspirations and $\mathrm{t} 1$ and $\mathrm{t} 2$ self-esteem ( $\mathrm{H} 3$ and $\mathrm{H} 4)$ and on further education (H5a). Additionally, we expect that $\mathrm{t} 1$ ability self-concept at school influences the probability of undertaking a further education after apprenticeship (H5b).

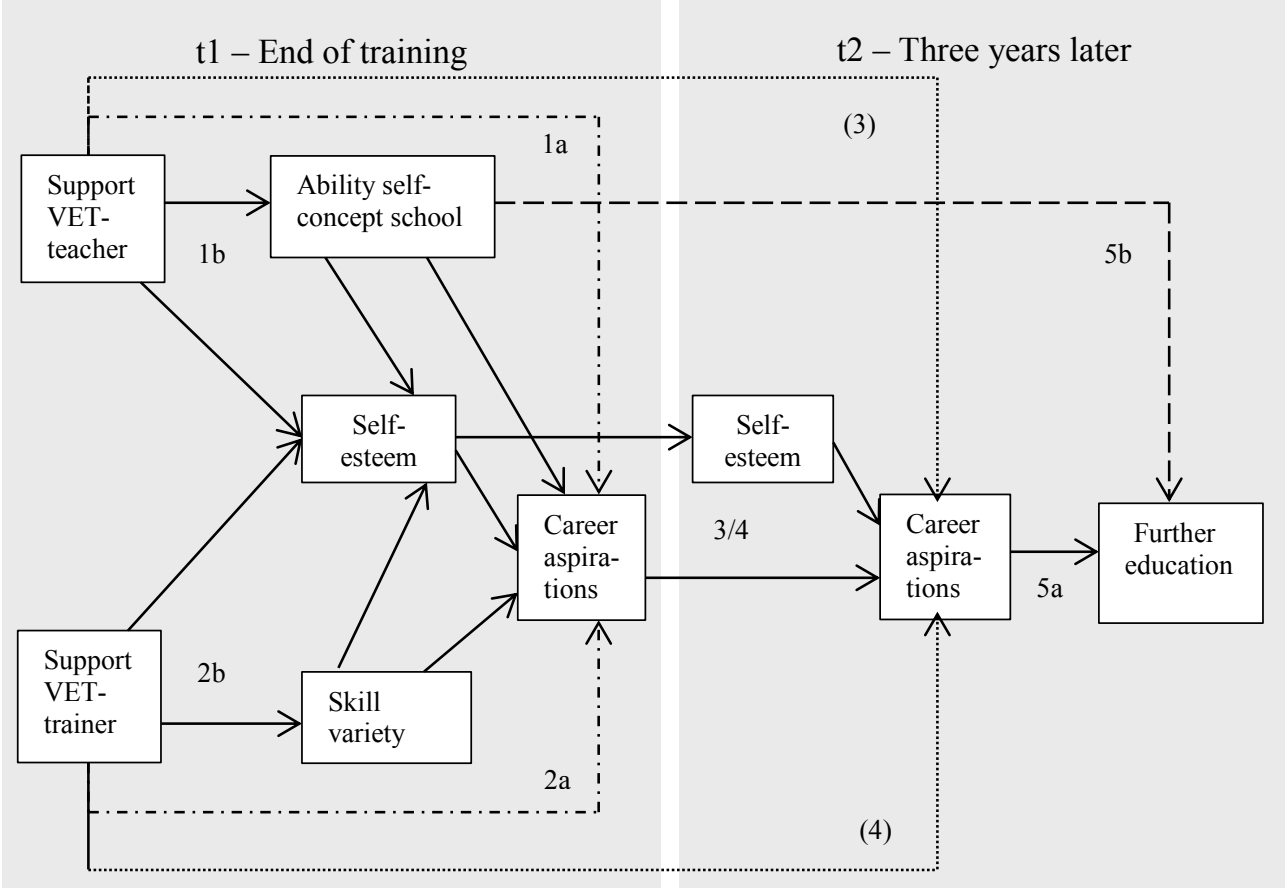

Figure 1: Hypothesised influences of social support on career aspirations/ situation at the end of the training and three years later 


\section{Method}

\subsection{Participants and procedure}

Participants were 525 young adults (Mean age 19.7 years at t1; SD=2.1 years; $62.5 \%$ females) who responded to a written survey at the end of their two-year vocational training (t1) and three years later (t2). More than half of the participants $(57.1 \%)$ had at least one parent not born in Switzerland. Before entering vocational training, $22.1 \%$ had attended special classes or schools for pupils with learning difficulties.

At t1, 185 participants (35.2\%) worked in sales; 134 (25.5\%) in gastronomy, $106(20.2 \%)$ in home economics, and $100(19.1 \%)$ in joinery.

The first ( $\mathrm{t} 1$ ) survey was administered in a classroom setting either in June 2007 (319 participants) or in June 2009 (206 participants). Researchers were present to answer questions. The response rate at $\mathrm{t} 1$ was $100 \%$. Three years later (t2), participants were contacted by phone and interviewed using a semi-structured questionnaire. Response rate was $51.1 \%(\mathrm{n}=268)$.

The analysis of missing data shows no significant systematic dropouts regarding gender, former school career, migration background or sectors. Furthermore, there is no significant difference between drop-outs and people taking part at both measurement time-points regarding the $\mathrm{t} 1$ constructs in our model (VET-teacher support, VET-trainer support, self-esteem, skill variety, ability selfconcept VET-school, career aspirations).

\subsection{Measures}

\subsubsection{Social support from VET-teachers and VET-trainers}

Social support from teachers at the VET-school and trainers at the VET-company was measured at t1 with two items each, based on the social support scale developed by Frese (1999) that was adapted by the TREE panel study (Stalder, Meyer and Hupka-Brunner, 2011) The introductory questions were: (1) 'How interested are the following persons in your training situation?' and (2) 'How much can you rely on the following persons if the vocational training situation gets difficult?', each followed by a list of possible supporters (i.a., VET-teacher, VETtrainer). The answer format was a 4-point Likert scale, ranging from 'not at all' $(=1)$ to 'very' $(=4)$. Cronbach- $\alpha$ for teacher's support at VET-school was .83 $(\mathrm{r}=.62)$; for VET-trainer's support at the VET-company, Cronbach- $\alpha$ was .76 $(\mathrm{r}=.72)$.

\subsubsection{Ability self-concept at VET-school}

To measure the ability self-concept for VET-school performance, we developed a two-item scale measuring self-perceived performance at VET-school. The two items were 'How do you assess your performance in occupation-specific knowledge classes?' and 'How do you assess your performance in general subjects classes?' The answer format was a 5-point Likert scale, ranging from 'bad' $(=1)$ to 'good' (=5); Cronbach- $\alpha$ for this scale was .78 $(\mathrm{r}=.63)$.

\subsubsection{Skill variety}

Skill variety was measured at t1 with a scale developed by Prümper, Hartmannsgruber and Frese (1995). The items were: 'At work I can learn a lot of new 
things', 'My work is varied' and 'At work I can use my knowledge and my skills fully'. The answer format was a 5-point-scale ranging from 'very rarely/never' $(=1)$, to, 'very often' (=5). Cronbach's $\alpha$ of this scale was .75.

\subsubsection{Self-esteem}

Self-esteem was measured at $\mathrm{t} 1$ and $\mathrm{t} 2$ with a scale based on Rosenberg (1979). Four items were selected: 'On the whole, I am satisfied with myself', 'I feel that I have a number of good qualities', 'I am able to do things as well as most other people' and 'I feel that I'm a person of worth, at least on an equal plane with others'. The answer format was a 4-point-scale ranging from 'not at all true' $(=1)$ to 'totally true' (=5). Cronbach's $\alpha$ of the scale was .72 at t1 and .59 at $\mathrm{t}^{2}$.

\subsubsection{Career aspirations}

To measure career aspirations, we used three items from a scale developed by Watermann (2000). At t 1 and $\mathrm{t} 2$, the apprentices were asked as follows: 'If you think about your future: What is important for you?' Selected items were: 'Having a work-situation where I can always learn something new', 'Having a worksituation where I can use my skills fully' or 'Having a job that offers me good possibilities for further education'. The answer format was a 4-point Likert scale ranging from 'not at all important' $(=1)$, to 'very important' $(=4)$. Cronbach's $\alpha$ for the scale was .65 at $\mathrm{t} 1$ and .60 at $\mathrm{t}^{3}$.

\subsubsection{Undertaking further education}

At $\mathrm{t} 2$, the young workers described their actual professional situation by selecting one of ten options (e.g., working in their learned occupation, undertaking further education for a federal VET-certificate or another further education, unemployed, etc.). Answers were coded $0=$ not undertaking further education and $1=$ undertaking further education. In sum, 81 out of 268 persons $(30.2 \%)$ were undertaking further education or had already finished it at $\mathrm{t} 2$.

\section{Results}

\subsection{Descriptive statistics and measurement model}

Means, standard deviations and bivariate correlations between all included variables are presented in Table 1 . 
Table 1: Descriptive statistics and bivariate correlations of the involved scales

\begin{tabular}{|c|c|c|c|c|c|c|c|c|c|c|c|}
\hline & $\mathrm{N}$ & M & SD & 1 & 2 & 3 & 4 & 5 & 6 & 7 & 8 \\
\hline $1 \mathrm{t} 1 \mathrm{STE}$ & 494 & 3.22 & .83 & - & & & & & & & \\
\hline 2 t1 STR & 501 & 3.33 & .86 & $.43^{* *}$ & - & & & & & & \\
\hline $3 \mathrm{t} 1 \mathrm{SEL}$ & 517 & 3.95 & .63 & $.15^{* *}$ & $.19^{* *}$ & - & & & & & \\
\hline $4 \mathrm{t} 1 \mathrm{ASC}$ & 524 & 3.81 & .71 & $.15^{* *}$ & .09 & $.30^{* *}$ & - & & & & \\
\hline $5 \mathrm{t} 1 \mathrm{SVA}$ & 523 & 3.87 & .75 & $.14^{* *}$ & $.40^{* *}$ & $.35^{* *}$ & $.22^{* *}$ & - & & & \\
\hline $6 \mathrm{t} 1 \mathrm{CAS}$ & 516 & 3.34 & .53 & $.26^{* *}$ & $.22^{* *}$ & $.36^{* *}$ & $.24^{* *}$ & $.25^{* *}$ & - & & \\
\hline 7 t 2 SEL & 265 & 4.36 & .50 & .07 & .11 & $.26^{* *}$ & .09 & $.15^{*}$ & $.16^{* *}$ & - & \\
\hline 8 t2 CAS & 266 & 3.61 & .43 & .00 & .10 & .00 & -.02 & .00 & .06 & $.22^{* *}$ & \\
\hline $9 \mathrm{t} 2 \mathrm{FE}^{1}$ & 268 & .30 & - & .05 & .10 & .04 & $.20^{* *}$ & .01 & .10 & .07 & $.12^{\mathrm{t}}$ \\
\hline
\end{tabular}

Notes. ${ }^{\mathrm{t}} \mathrm{p}>.10^{*} \mathrm{p}<.05,{ }^{* *} \mathrm{p}<.01,{ }^{* * *} \mathrm{p}<.001$, STE=Support VET-Teacher, STR=Support VET-Trainer, $\mathrm{ASC}=$ Ability self-concept, $\mathrm{SVA}=$ Skill variety, $\mathrm{SEL}=$ Self-esteem, $\mathrm{CAS}=$ Career aspirations, $\mathrm{FE}=$ Further education, ${ }^{1}$ Spearmans rank correlation coefficient

To examine the hypothesised relationships (Fig. 1), a two-step procedure was undertaken using MPlus: First, we estimated a measurement model to test the discriminant validity of the involved constructs (Muthén and Muthén, 2012). In a second step, we tested and compared several structural models with direct and mediated paths.

In the measurement model, each construct was represented by a latent factor which was allowed to correlate with the others. We used a rescaling-based robust estimator MLR in MPlus as recommended by Wang and Wang (2012) to deal with skewness and kurtosis in our data and obtain robust estimates. Measurement errors of the repeated measures at $\mathrm{t} 1$ and $\mathrm{t} 2$ (self-esteem, career aspirations) were allowed to correlate as recommended for autoregressive models (Christ and Schlüter, 2012). To assess the adequacy of the measurement model, we refer to the comparative fit index (CFI), Tucker-Lewis index (TLI) and the root-mean-square error of approximation (RMSEA). CFI and TLI values greater than or equal to .95 and RMSEA lower than .05 suggests 'good fit' of a model (Wang and Wang, 2012). We tested measurement invariance for the repeated measures (self-esteem, career aspirations). Results of this separate analysis showed strong measurement invariance for both concepts ${ }^{4}$.

To deal with missing data, a Full Maximum Likelihood method (FIML) approach is used. It uses all the information of the observed data and maximises the likelihood of the model given the observed data (Wang and Wang, 2012). In the situation of missing at random (as our drop-out analysis shows we have), FIML is more efficient and less biased than traditional approaches (Peugh and Endersen, 2004). This is especially important for longitudinal analyses with severe panel mortality, as is the case in this study.

$4 \quad$ This means that setting loadings and means equal at $\mathrm{t} 1$ and $\mathrm{t} 2$ did not significantly worsen the model fit, measured with a $\mathrm{Chi}^{2}$-Difference Test as recommended by Christ and Schlüter (2012). 


\subsection{Measurement model}

Results of this first step showed that all indicators significantly loaded on their specified latent construct, most of them with high factor loadings. This provides psychometric support for the selected items and their respective scale. Model fit indices were $\mathrm{CFI}=.930, \mathrm{TLI}=.915$ and $\mathrm{RMSEA}=.037$ at first. Modification indices point to shared measurement errors, probably caused by similar wordings for the support items (Byrne, 2010; Diemer, 2007). We therefore allowed two of these errors to correlate ${ }^{5}$. The final measurement model showed good fit indices $(\mathrm{CFI}=.952, \mathrm{TLI}=.942, \mathrm{RMSEA}=.031)$.

\subsection{Structural model: Pathways from social support to career aspirations}

To test our hypotheses (Fig. 1) and decide whether paths are only indirect or direct (fully or partially mediated models), we evaluated different nested models by comparing their goodness of fit indices with a Chi-Square Difference-Test (see Restubog et al., 2010). The basic idea is that we accept the partially mediated model for reasons of parsimony only if the resulting Chi-Square Difference is significant, meaning that the additional direct path improved the fit significantly compared to the fully mediated model.

We started with a fully mediated Model A and specified the different indirect paths $^{6}$ (see Table 2 for fit indices and path coefficients). For Model B, we added two direct paths from $t 1$ teacher support to $t 1$ career aspirations (H1a) and from $t 1$ VET-trainer support to t1 career aspiration (H2a). A comparison of Model A and B showed a significant better fit for Model $\mathrm{B}(\Delta \mathrm{MLR}=12.57, \mathrm{df}=2, \mathrm{p}=.002)$. Thus, our results support the partially mediated Model B. The fit statistics for this model were $\operatorname{good}(\mathrm{CFI}=.965, \mathrm{TLI}=.955, \mathrm{RMSEA}=.036)$.

Next we included $\mathrm{t} 2$ and first added $\mathrm{t} 2$ self-esteem and $\mathrm{t} 2$ career aspirations (using our final t1-Model B as a base). We again tested the two models against each other: For Model C, we assumed that effects of $\mathrm{t} 1$ support (VET-teachers and VET-trainers) on $\mathrm{t} 2$ career aspirations are only indirect via $\mathrm{t} 1$ variables and $\mathrm{t} 2 \mathrm{self}$ esteem (H3, H4).

For the competitive Model D, we added two additional direct paths from $\mathrm{t} 1$ VET-teacher support and t1 VET-trainer support to t2 career aspirations. Comparison of the two models $\mathrm{C}$ and $\mathrm{D}$ showed that the partially mediated model $\mathrm{D}$ was not significantly better than the fully mediated model $\mathrm{C}(\triangle \mathrm{MLR}=1.972$ $\mathrm{df}=2, \mathrm{p}=0.373$ ). Therefore, we can conclude that the parsimonious full mediation model is preferable. The fit statistics for model $\mathrm{C}$ were good (CFI=.947, TLI=.941, RMSEA=.031).

5 Errors between VET-teacher support 'interest in training situation' (see 3.2.1.) and VET-trainer support 'interest in training situations' and between VET-teacher support 'difficult training situations' and VET-trainer support 'difficult training situations' were allowed to correlate.

6 The interrelations between $\mathrm{t} 1$ VET-teacher and VET-trainer support, $\mathrm{t} 1$ ability selfconcept at VET-school, t1 skill variety, t1 self-esteem and $\mathrm{t} 1$ career aspirations were assessed separately with similar comparative analyses. It turned out that there are no direct effects from VET-teacher or VET-trainer support on t1 self-esteem but only indirect paths via ability self-concept resp. skill variety. Furthermore, there were no direct paths from $\mathrm{t} 1$ ability self-concept and from t1 skill variety to t1 career aspirations, but self-esteem fully mediated these relations (see Fig. 2). 
Lastly, we included 'undertaking further education' in the Model $\mathrm{E}^{7}$ and specified a path from $\mathrm{t} 2$ career aspirations to $\mathrm{t} 2$ further education (H5a) and a path from $\mathrm{t} 1$ ability self-concept at VET-school to t2 further education (H5b).The final Model $\mathrm{E}$ has acceptable fit statistics (CFI=.932, TLI=.923, RMSEA=.031).

Fit indices and path coefficients (direct and indirect paths) for each of the five models A-E are presented in Table 2:

Table 2: Direct and indirect paths from t1 VET-trainer support and t1 VETteacher support to $\mathbf{t} 1 / \mathbf{t} 2$ career aspirations and $\mathbf{t} 2$ further education $(\mathrm{N}=525)$

\begin{tabular}{|c|c|c|c|c|c|}
\hline Fit Indices and paths & $\begin{array}{l}\text { Model A } \\
\text { Full med. } \\
\text { t1 }\end{array}$ & $\begin{array}{l}\text { Model B } \\
\text { Part. } \\
\text { med. t1 }\end{array}$ & $\begin{array}{l}\text { Model C } \\
\text { Full med. } \\
\text { t2 }\end{array}$ & $\begin{array}{l}\text { Model D } \\
\text { Part. } \\
\text { med. t2 }\end{array}$ & $\begin{array}{l}\text { Model E } \\
+ \text { further } \\
\text { education }\end{array}$ \\
\hline$\chi^{2}$ & 173.49 & 158.63 & 337.57 & 335.74 & 359.04 \\
\hline DF & 96 & 94 & 224 & 222 & 243 \\
\hline CFI & 0.957 & 0.965 & 0.947 & 0.947 & 0.932 \\
\hline TLI & 0.947 & 0.955 & 0.941 & 0.940 & 0.923 \\
\hline RMSEA & 0.039 & 0.036 & 0.031 & 0.031 & 0.030 \\
\hline $\mathrm{t} 1 \mathrm{STE} \rightarrow \mathrm{t} 1 \mathrm{ASC}$ & $0.230^{* * *}$ & $0.229^{* * *}$ & $0.231^{* * *}$ & $0.232^{* * *}$ & $0.279^{* * *}$ \\
\hline $\mathrm{t} 1 \mathrm{ASC} \rightarrow \mathrm{t} 1 \mathrm{SEL}$ & $0.378^{* * *}$ & $0.370^{* * * *}$ & $0.373^{* * *}$ & $0.374^{* * *}$ & $0.404^{* * *}$ \\
\hline $\mathrm{t} 1 \mathrm{STR} \rightarrow \mathrm{t} 1 \mathrm{SVA}$ & $0.513^{* * *}$ & $0.511^{* * *}$ & $0.512^{* * *}$ & $0.510^{* * *}$ & $0.517^{* * *}$ \\
\hline $\mathrm{t} 1 \mathrm{SVA} \rightarrow \mathrm{t} 1 \mathrm{SEL}$ & $0.432^{* * *}$ & $0.418^{* * *}$ & $0.414^{* * *}$ & $0.413^{* * *}$ & $0.479^{* * *}$ \\
\hline $\mathrm{t} 1 \mathrm{SEL} \rightarrow \mathrm{t} 1 \mathrm{CAS}$ & $0.564^{* * *}$ & $0.481^{* * *}$ & $0.508^{* * *}$ & $0.508^{* * *}$ & $0.554^{* * *}$ \\
\hline t1STE $\rightarrow$ t1CAS total & $0.049^{* *}$ & $0.263^{* * *}$ & $0.252^{* * *}$ & $0.248^{* * *}$ & $0.302^{* * *}$ \\
\hline $\mathrm{t} 1 \mathrm{STE} \rightarrow \mathrm{t} 1 \mathrm{CAS}$ direct & - & $0.223^{* *}$ & $0.208^{* *}$ & $0.204^{* *}$ & $0.240^{* * *}$ \\
\hline $\begin{array}{l}\text { t1STE } \\
\text { indirect }\end{array}$ & $0.049^{* *}$ & $0.041^{* *}$ & $0.044^{* *}$ & $0.044^{* *}$ & $0.062^{* * *}$ \\
\hline t1STR $\rightarrow$ t1CAS total & $0.125^{* * *}$ & $0.161^{*}$ & $0.171^{*}$ & $0.176^{*}$ & $0.153^{* *}$ \\
\hline $\mathrm{t} 1 \mathrm{STR} \rightarrow \mathrm{t} 1 \mathrm{CAS}$ direct & - & 0.059 & 0.064 & 0.069 & 0.016 \\
\hline $\begin{array}{l}\text { t1STR } \rightarrow \quad \text { t1CAS } \\
\text { indirect }\end{array}$ & $0.125^{* * *}$ & $0.103^{* * *}$ & $0.107^{* * *}$ & $0.107^{* * *}$ & $0.137^{* * *}$ \\
\hline $\mathrm{t} 1 \mathrm{SEL} \rightarrow \mathrm{t} 2 \mathrm{SEL}$ & - & - & $0.302^{* *}$ & $0.301^{* *}$ & $0.351^{* * * *}$ \\
\hline $\mathrm{t} 1 \mathrm{CAS} \rightarrow \mathrm{t} 2 \mathrm{CAS}$ & - & - & -0.074 & -0.103 & -0.136 \\
\hline $\mathrm{t} 2 \mathrm{SEL} \rightarrow \mathrm{t} 2 \mathrm{CAS}$ & - & - & $0.400^{* * *}$ & $0.390^{* * *}$ & $0.349^{* * *}$ \\
\hline t1STE $\rightarrow$ t2CAS total & - & - & -0.008 & -0.105 & -0.028 \\
\hline $\mathrm{t} 1 \mathrm{STE} \rightarrow \mathrm{t} 2 \mathrm{CAS}$ direct & - & - & - & -0.089 & -0.000 \\
\hline $\mathrm{t} 1 \mathrm{STE} \rightarrow \mathrm{t} 2 \mathrm{CAS}$ indirect & - & - & -0.008 & -0.015 & -0.027 \\
\hline $\begin{array}{l}\text { t1STE } \rightarrow \text { t2CAS } \\
\text { spez.ind. }^{8}\end{array}$ & - & - & $0.010^{*}$ & $0.010^{*}$ & $0.014^{*}$ \\
\hline t1STR $\rightarrow$ t2CAS total & - & - & 0.013 & 0.174 & 0.120 \\
\hline $\mathrm{t} 1 \mathrm{STR} \rightarrow \mathrm{t} 2 \mathrm{CAS}$ direct & - & - & - & 0.168 & 0.110 \\
\hline $\begin{array}{ll}\text { t1STR } & \rightarrow \text { t2CAS } \\
\text { indirect } & \end{array}$ & - & - & 0.013 & 0.007 & 0.009 \\
\hline $\begin{array}{l}\text { t1STR } \rightarrow \text { t2CAS } \\
\text { spez.ind. }{ }^{9}\end{array}$ & & & $0.026^{*}$ & $0.025^{*}$ & $0.030^{* *}$ \\
\hline $\mathrm{t} 2 \mathrm{CAS} \rightarrow \mathrm{t} 2 \mathrm{FE}$ & - & - & - & - & $0.208^{*}$ \\
\hline
\end{tabular}

$7 \quad$ Model E includes a categorical variable 'undertaking further education': yes/no. The adequate estimator recommended by Wang and Wang (2012) is 'mean and varianceadjusted weight least squares' (WLMSV). Due to this change of estimator, path coefficients may have changed additionally from Model D to Model E.

8 Only one significant specific indirect path, via t1 ASC, t1SEL, t2SEL

9 Only one significant specific indirect path, via t1SVA, t1SEL, t2SEL 


\begin{tabular}{|c|c|c|c|c|c|}
\hline $\mathrm{t} 1 \mathrm{ASC} \rightarrow \mathrm{t} 2 \mathrm{FE}$ & - & - & - & - & $0.302^{* * *}$ \\
\hline $\mathrm{t} 1 \mathrm{STE} \rightarrow \mathrm{t} 2 \mathrm{FE}$ indirect & - & - & - & - & 0.078 \\
\hline $\begin{array}{l}\mathrm{t} 1 \mathrm{STE} \rightarrow \mathrm{t} 2 \mathrm{FE} \\
\text { spez.ind. }^{10}\end{array}$ & - & - & - & - & $0.084^{* *}$ \\
\hline $\mathrm{t} 1 \mathrm{STR} \rightarrow \mathrm{t} 2 \mathrm{FE}$ indirect & - & - & - & - & 0.025 \\
\hline $\begin{array}{l}\mathrm{t} 1 \mathrm{STR} \rightarrow \mathrm{t} 2 \mathrm{FE} \\
\text { spez.ind. }{ }^{11}\end{array}$ & - & - & - & - & $0.006^{\mathrm{t}}$ \\
\hline \multicolumn{6}{|l|}{$\mathrm{R}^{2}$} \\
\hline t1ASC & $0.053^{*}$ & $0.053^{*}$ & $0.054^{*}$ & $0.054^{*}$ & $0.078^{*}$ \\
\hline t1SVA & $0.263^{* * *}$ & $0.261^{* * *}$ & $0.262^{* * *}$ & $0.260^{* * *}$ & $0.268^{* * *}$ \\
\hline t1SEL & $0.347^{* * *}$ & $0.328^{* * *}$ & $0.327^{* * *}$ & $0.327^{* * *}$ & $0.421^{* * *}$ \\
\hline t1CAS & $0.318^{* * *}$ & $0.350^{* * *}$ & $0.372^{* * *}$ & $0.373^{* * *}$ & $0.436^{* * *}$ \\
\hline t2SEL & & & 0.091 & 0.090 & $0.123^{*}$ \\
\hline $\mathrm{t} 2 \mathrm{CAS}$ & & & $0.155^{\mathrm{t}}$ & $0.174^{*}$ & $0.131^{*}$ \\
\hline $\mathrm{t} 2 \mathrm{FE}$ & & & & & $0.138^{*}$ \\
\hline
\end{tabular}

We next assessed the significance of the specific paths with MPlus to test our hypotheses (Muthén and Muthén, 2012) (see Table 2). In the final Model E, VETteacher support is related directly with $\mathrm{t} 1$ career aspirations $(\beta=.240, \mathrm{p}<.001)$ which supports H1a. The results further support H1b, predicting that this relationship is partially mediated by $\mathrm{t} 1$ ability self-concept, VET-school and t1 self-esteem $(\beta=.062, \mathrm{p}<.001)$. In contrast, VET-trainer support didn't have a significant direct effect. Thus $\mathrm{H} 2 \mathrm{a}$ is rejected. However we found a significant indirect path from VET-trainer support to t1 career aspirations $(\beta=.137, \mathrm{p}<.001)$. This supports $\mathrm{H} 2 \mathrm{~b}$, predicting that the relation between VET-trainer support and t1 career aspirations is mediated by skill variety and self-esteem.

The direct paths from t1 support (VET-teacher and VET-trainer) to t2 career aspirations are not significant, but we found a significant specific indirect path from VET-teacher support to 2 career aspirations via $t 1$ ability self-concept at VET-school, t1 self-esteem and $t 2$ self-esteem $(\beta=.014, p<.05)$. Similar results were obtained for VET-trainer support: We found a specific indirect path to t2 career aspirations via $\mathrm{t} 1$ skill variety, $\mathrm{t} 1$ self-esteem and $\mathrm{t} 2$ self-esteem $(\beta=.030$, $\mathrm{p}<.01$ ). These results support $\mathrm{H} 3$ and $\mathrm{H} 4$ expecting that (only) indirect paths lead from $\mathrm{t} 1$ support to career aspirations at $\mathrm{t} 2$.

As expected, relations from t 1 support to further education are only weak: For VET-teacher support, there is a specific indirect effect via ability self-concept at VET-school $(\beta=.084, \mathrm{p}<.01)$. For VET-trainer support, a near-significant indirect path leads to $\mathrm{t} 2$ further education via $\mathrm{t} 1$ skill variety, $\mathrm{t} 1$ self-esteem, $\mathrm{t} 2$ self-esteem and $\mathrm{t} 2$ career aspirations $(\beta=.006, \mathrm{p}<.1)$. Hence, results support H5a at least partially. Finally the path from $t 1$ ability self-concept $(\beta=.302, \mathrm{p}<.001)$ is highly significant. Thus Hypothesis $5 \mathrm{~b}$ is confirmed.

The final Model E is presented in Figure 2.

\footnotetext{
10 Only one significant specific indirect path, via t1ASC

11 One nearly significant specific indirect path, via t1SVA, t1SEL, t2SEL, T2CAS
} 


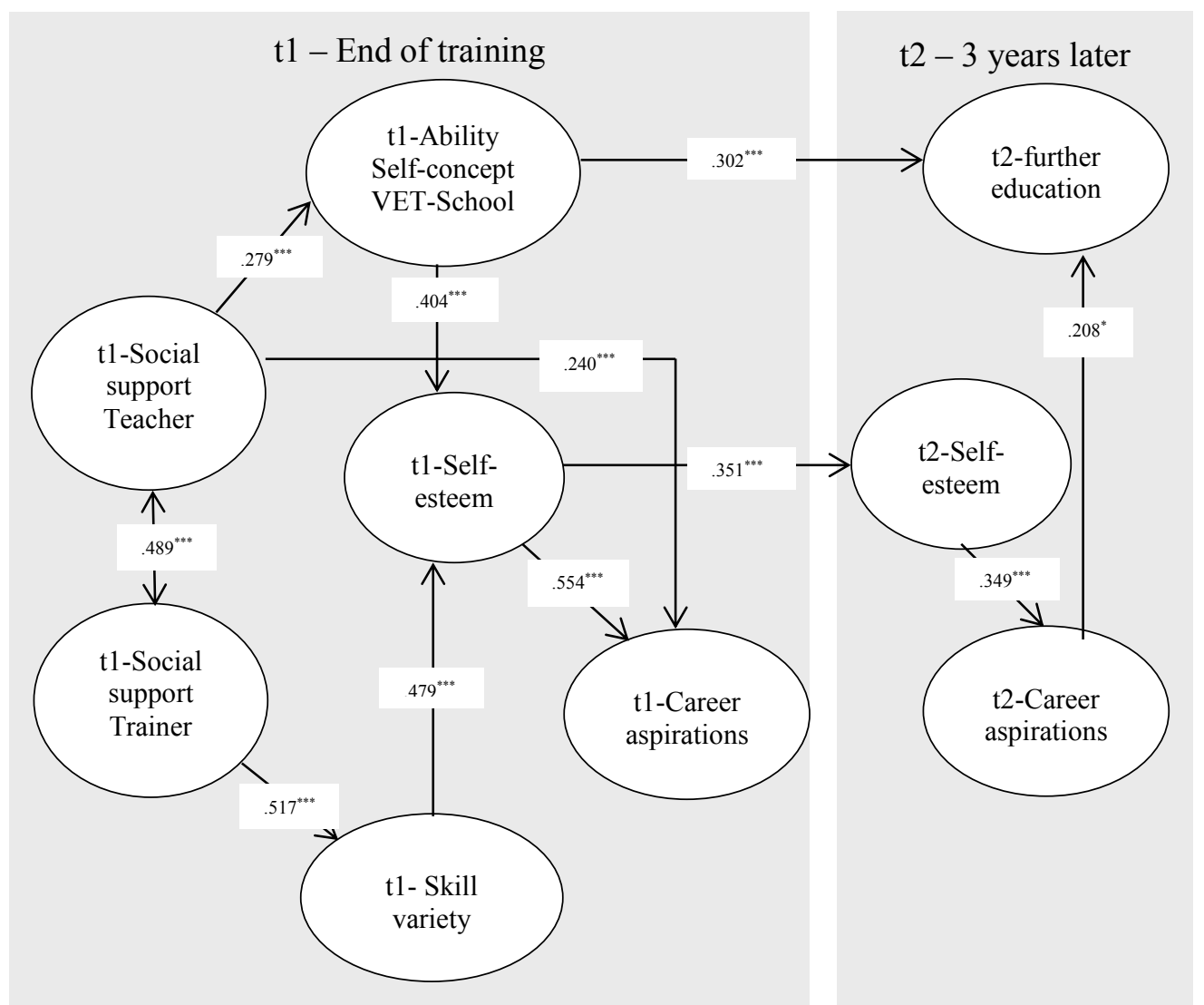

Figure 2: Influences of social support on career aspirations at the end of the training and three years later (only significant paths, $N=525$ )

\section{$5 \quad$ Discussion and conclusions}

The goal of this study was to expand our understanding of the relationships between support during VET and career development for young adolescents with learning difficulties. We argued that the two learning environments (VET-school, VET-company) with their specific demands, offer different support opportunities and modalities. We therefore hypothesised different paths between VET-teacher support and VET-trainer support to career outcomes.

Our final structural model supported the general hypothesis that indirect paths are important in this context. As predicted, VET-teacher support positively influenced ability self-concept at VET-school and in this way self-esteem and career aspirations at the end of the apprenticeship. Moreover, VET-teacher support was directly related to career aspirations. Things are different for VET-trainer support where we only found indirect effects on career aspirations via skill variety and self-esteem, but these paths were stronger than VET-teacher's indirect effects.

This difference-direct effects for the VET-school environment and indirect effects only for the VET-company environment-makes sense if we consider the different conditions and cultures of the two learning contexts. At the VETcompany, training is embedded in the production process and apprentices participate in everyday work situations (Stalder and Nägele, 2011). Learning and practicing of skills is done under the supervision of the VET-trainer or an experienced worker colleague. Thus feedback and coaching of the VET-trainer is 
closely related to company-specific tasks and often takes place under time pressure (see Berweger et al., 2013). Vocational schools on the other hand complement and expand the practical training of the companies by providing theoretical knowledge in the occupational field and in general subjects (Stalder and Nägele, 2011). VETteachers knowledge transfer is based more on communication and direct instruction, and they provide learning content aimed at the practice of the profession in general (Neuenschwander et al., 2012). Therefore, career prospects and planning are probably more prominent in this context.

However, the importance of the indirect paths in both areas supports previous findings in this context (e.g., Pan et al., 2011; Pinquart et al., 2003). Contrary to expectations, we did not find direct effects of VET-teacher or VET-trainer support on self-esteem. The respective paths were completely mediated by domain specific beliefs ('ability self-concept at VET-school') or opportunities at the VET-company ('skill variety'). VET-teachers and VET-trainers are probably most credible in their own sphere of influence (see Thoits, 2011), and their direct influence on more stable constructs as self-esteem is limited. Nonetheless, self-esteem is essential for the pathway from support to career aspirations: As our results show, self-esteem mediates the relation between the two domain-specific concepts and career aspirations. We conclude that this more general self-evaluation serves to integrate domain specific information about the self in view of future career options.

Our findings concerning the cross-sectional relations at $\mathrm{t} 1$ are a contribution to identifying some of the underlying processes involved in different supporting relationships in the two learning contexts of VET. On the other hand, and in line with other studies (e.g., Diemer, 2007; Frese, 1999), we had problems detecting longitudinal effects over three years of social support in general and finding effects on behaviour (undertaking further education) in particular. Even career aspirations themselves were not stable from t 1 to $\mathrm{t} 2$. The lack of significant longitudinal effects may be due to different reasons. First of all, we asked at the end of the training for effects of past support (during apprenticeship) and related it to later career aspirations in a work-situation usually not in the same company. Secondly, we have an interval of three years. In these three years, all young adults changed from an educational context into the labour market. During the three year period, most likely, additional factors (e.g., support from work colleagues, worksatisfaction) were relevant for career motivation and aspirations and probably caused instability of career aspirations as well.

\subsection{Limitations and further research needs}

This study has some limitations. First off, our sample-size was at the lower end of what is necessary to examine complex interrelations. This may have restricted the power needed to obtain significant results. Indeed, Wang and Wang (2012) recommend as a rule of thumb that the minimum sample size should be at least five times the number of free parameters; with kurtotic data even more. This is a particular concern for $\mathrm{t} 2$ where we have an $\mathrm{N}$ of only 268 . The response rate is $51 \%$, which is usual, but nevertheless high, panel mortality.

Secondly, causality cannot be inferred for our cross-sectional results (t1). Based on theory and past research, the proposed causal order is reasonable, but other directions of influence cannot be excluded. While some reverse relationships are not convincing (e.g., that career aspirations influence self-esteem), others are possible. For example, it can be argued that people with high self-esteem are more proactive in their careers and hence more likely to search for support and to find 
work contexts that offer learning possibilities. Furthermore, people's career success could increase the chances of obtaining a mentor (Whitely, 1991 in Day; Allen, 2004, p. 87). However, we think that in our context (apprenticeship for apprentices with learning difficulties and special needs), support is more institutionalised. Thus the need for support should elicit support independent of the apprentice's motivation. In any case, longitudinal studies with more measurement points would allow for cross-lagged models and causality conclusions.

Thirdly, this study relies on self-reports as the method of data collection. With the exception of 'undertaking further education' (which is, as factual information, probably less likely to suffer from problems of common method variance; Day and Allen, 2004), all other variables are subjective. Furthermore, we cannot exclude social desirability effects. Although it may be that the problem of common method variance has been overstated (Spector, 2006), future research should include multisource ratings. It would be especially interesting to have information about the quantity and quality of support from the perspective of the supporters (VETteacher, VET-trainer). Additionally, family support and interaction effects between different support sources (e.g., between private and professional support) could be included in more elaborated models.

\subsection{Practical implications}

Given the limited resources that young people with learning difficulties have, maximizing the impact of professional support upon their career development in both learning environments is vital. VET-teacher's direct influence on career aspirations (and via ability self-concept on undertaking further education) seems to be essential. The key role of the VET-teacher also implies a high responsibility to give adequate feedback and really recognise the potential of some apprentices (without neglecting the others). VET-teachers normally have many students at the same time, and they may thus underestimate the importance of their influence on their students. It is important to inform VET-teachers about their crucial role.

Trainers at the VET-company are in another position, as already mentioned above. Offering a wide range of tasks and 'skill variety' seems crucial, and it is important that VET-companies and VET-trainers are aware of this. Moreover, it may be possible to strengthen direct positive effects of VET-trainers (or colleagues at the VET-company) on career aspirations by making career planning and further education a more important subject of discussion in the VET-company. However, both learning sites address theoretical and practical issues, and cooperation between VET-schools and VET-companies is essential and has already been strengthened (Stalder and Nägele, 2011), especially in the two-year VET-program.

Finally, it is important to note that career support does not necessarily end with the end of the training and successful graduation. For though the rate of $95 \%$ with a qualification at the upper secondary level has almost been met, the youth unemployment rate in Switzerland increased (OECD, 2013). Young workers with learning difficulties are especially at risk here. New models aimed to facilitate labour-market entry are evaluated under the label of 'supported employment', which promises longer-lasting professional integration and employability, especially for weaker employees in the labour market. 


\section{References}

Byrne, B. M. (2010). Structural Equation Modeling with AMOS. Basic Concepts, Applications, and Programming (2 ed.). New York: Routledge Taylor \& Francis Group.

Abele, A. E., \& Spurk, D. (2009). The longitudinal impact of self-efficacy and career goals on objective and subjective career success. Journal of Vocational Behavior, 74, 53-62.

Beal, S. J., \& Crocket, L. J. (2010). Adolescents' occupational and educational aspirations and expectations: Links to high school activities and adult educational attainment. Developmental Psychology, 46(1), 258-265.

Berweger, S., Krattenmacher, S., Salzmann, P., \& Schönenberger, S. (2013). LiSA. Lernende im Spannungsfeld von Ausbildungserwartungen, Ausbildungsrealität und erfolgreicher Erstausbildung. St. Gallen: Pädagogische Hochschule. Institut Professionsforschung und Kompetenzentwicklung.

Byrne, B. M. (2010). Structural Equation Modeling with AMOS. Basic Concepts, Applications, and Programming (2nd ed.). New York: Routledge Taylor \& Francis Group.

Chrisopoulos, S., Dollard, M., F., Winefield, A. H., \& Dormann, C. (2010). Increasing the probability of finding an interaction in work stress research: A two-wave longitudinal test of the triple-match principle. Journal of Occupational and Organizational Psychology, 83(1), 17-37.

Christ, O., \& Schlüter, E. (2012). Strukturgleichungsmodelle mit Mplus. Eine praktische Einführung. München: Oldenbourg Verlag.

Cohen, S., \& Wills, T. A. (1985). Stress, social support, and the buffering hypothesis. Psychological Bulletin, 98(2), 310-357.

Creed, P., Fallon, T., \& Hood, M. (2009). The relationship between career adaptability, person and situation variables, and career concerns in young adults. Journal of Vocational Behavior, 74, 219-229.

Day, R., \& Allen, T. D. (2004). The relationship between career motivation and self-efficacy with protégé career success. Journal of Vocational Behavior, 64, 72-91.

Diemer, M. A. (2007). Parental and school influences upon the career development of poor youth of color. Journal of Vocational Behavior, 70, 502-524.

Felkendorf, K., \& Lischer, E. (Eds.). (2005). Barrierefreie Übergänge? Jugendliche mit Behinderungen und Lernschwierigkeiten zwischen Schule und Berufsleben. Zürich: Verlag Pestalozzianum.

Frese, M. (1999). Social Support as a moderator of the relationship between work stressors and psychological dysfuncioning: a longitudinal study with objective measures. Journal of Occupational Health Psychology, 4(3), 179-192.

Grob, A., \& Jaschinski, U. (2003). Erwachsen werden. Entwicklungspsychologie des Jugendalters (1. Auflage ed.). Weinheim, Basel, Berlin: Beltz Verlag.

Hackett, G., Betz, N. E., Casas, J. M., \& Rocha-Singh, I. (1992). Gender, ethnicity, and social cognitive factors predicting the academic achievement of engineering majors. Journal of Counseling Psychology, 39, 527-538.

Hackman, J. R. (1980). Work redesign and motivation. Professional Psychology, 11(3), 445-455.

Häfeli, K., \& Schellenberg, C. (2009). Erfolgsfaktoren in der Berufsbildung bei gefährdeten Jugendlichen. Bern: EDK Schweizerische Erziehungs- 
direktoren Konferenz.

Harris, I. (2007). Types of Workplace Social Support in the prediction of job satisfaction. The Career Development Quarterly, 56, 150-156.

Heinz, W. R. (2002). Transition discontinuities and biographical shaping of early work careers. Journal of Vocational Behavior, 60, 220-240.

House, J. S. (1981). Work Stress and Social Support. Reading Massachusetts: Addison-Wesley Publishing Company.

Hupka, S., Sacchi, S., \& Stalder, B. E. (2006). Does the Swiss VET System encourage inequity? Paper presented at the European Research Network on Transitions in Youth TIY, Marseilles.

Kammermann, M. (2010). Job or further training? Impact of the Swiss Basic Federal Vocational Education and Training (VET) Certificate on the careers of low achieving young people. Education + Training, 52(5), 391403.

Kammermann, M., Amos, J., Hofmann, C., \& Hättich, A. (2009). Integriert in den Arbeitsmarkt? Personen mit Berufsattest im Detailhandel und im Gastgewerbe ein Jahr nach Ausbildungsabschluss. In H. f. Heilpädagogik (Ed.). Zürich: Hochschule für Heilpädagogik.

Kammermann, M., Stalder, B. E., \& Hättich, A. (2011). Two-year apprenticeships - A successful model of training? Journal of Vocational Education and Training, 63(3), 377-396.

Laireiter, A. (1993). Soziales Netzwerk und soziale Unterstützung: Konzepte, Methoden und Befunde. Bern, Götingen, Toronto, Seattle: Huber.

Lent, R. W., Brown, S. D., Brenner, B., Chopra, S. B., Davis, T., Talleyrand, R., \& Suthakaran, V. (2001). The role of contextual supports and barriers in the choice of math/science educational options: A test of social cognitive hypotheses. Journal of Counseling Psychology, 48(4), 474-483.

Lent, R. W., Brown, S. D., \& Hackett, G. (2000). Contextual supports and barriers to career choice: A social cognitive analysis. Journal of Counseling Psychology, 47(1), 36-49.

Lent, R. W., Brown, S. D., Schmidt, J., Brenner, B., Lyons, H., \& Treistman, D. (2003). Relation of contextual supports and barriers to choice behavior in engeneering majors: Test of alternative social cognitive models. Journal of Counseling Psychology, 50(4), 458-465.

Linnehan, F. (2003). A longitudinal study of work-based, adult-youth mentoring. Journal of Vocational Behavior, 63, 40-54.

Maier, G. W., \& Brunstein, J. C. (2001). The role of personal work goals in newcomers' Job satisfaction and organizational commitment: a longitudinal analysis. Journal of Applied Psychology, 86(5), 1034-1042.

Muthén, L. K., \& Muthén, B. O. (2012). Mplus. Statistical Analyses with Latent Variables. User's Guide (7th ed.). Los Angeles: CA: Muthén \& Muthén.

Neuenschwander, M. P., Frey, M., \& Gasser, L. (2007). Übergang in die Sekundarstufe II und Wirkungen der Berufsbildung. Zürcher Ergänzungsstudie Berufsbildung - Schlussbericht. Zürich: Jacobs Center for Productive Youth Development, Universität Zürich.

Neuenschwander, M. P., Gerber, M., Frank, N., \& Rottermann, B. (Eds.). (2012). Schule und Beruf. Wege in die Erwerbstätigkeit. Wiesbaden: VS Verlag.

Neuenschwander, M. P., \& Grunder, H.-U. (Eds.). (2010). Schulübergang und Selektion. Zürich/Chur: Rüegger Verlag.

Ng, T. W. H., Eby, L. T., Sorensen, K. L., \& Feldman, D. C. (2005). Predictors of 
objective and subjective career success: A meta-analysis. Personnel Psychology, 58, 367-408.

Nurmi, J.-E., Salmela-Aro, K., \& Koivisto, P. (2002). Goal importance and related achievement beliefs and emotions during the transition from vocational school to work: Antecedents and consequences. Journal of Vocational Behavior, 60, 241-261.

OECD (2000). From Initial Education to Working Life. Making Transitions Work. Paris: OECD.

OECD (2013). Education at a Glance 2013: OECD Indicators, OECD Publishing.

Pan, W., Sun, L.-Y., \& Hau Siu Chow, I. (2011). The impact of supervisory mentoring on personal learning and career outcomes: The dual moderating effect of self efficacy. Journal of Vocational Behavior, 78, 264-273.

Peugh, J. L., \& Endersen, C. K. (2004). Missing data in educational research: A review of reporting practices and suggestions for improvement. Review of Educational Research, 74(4), 525-556.

Pinquart, M., Juang, L., \& Silbereisen, R. K. (2003). Self-efficacy and successful school-to-work transition: A longitudinal study. Journal of Vocational Behavior, 63, 329-346.

Prümper, J., Hartmannsgruber, K., \& Frese, M. (1995). KFZA. Kurz-Fragebogen zur Arbeitsanalyse. Zeitschrift für Arbeits- und Organisationspsychologie, 39(3), 125-131.

Restubog, S. L. D., Florentino, A. R., \& Garcia, P. R. J. M. (2010). The mediating roles of career self-efficacy and career decidedness in the relationship between contextual support and persistence. Journal of Vocational Behavior, 77, 186-195.

Rice, L., Barth, J. M., Guadagno, R. E., Smith, G. P. A., \& McCallum, D. M. (2013). The role of social support in Students' Perceived Abilities and Attitudes Toward Math and Science. Journal of Youth Adolescence, 42, $1028-1040$.

Rosenberg, M. (1979). Conceiving the self. New York: Basic Books.

Schellenberg, C., \& Hofmann, C. (2013). Fit für die Berufslehre! Forschungsbericht zur Berufswahlvorbereitung an der Schule bei Jugendlichen mit besonderem Förderbedarf. Bern: SZH-Verlag.

Semmer, N. K., \& Beehr, T. A. (2014). Job control and social aspects of work. In M. C. W. Peeters, J. de Jonge \& T. W. Taris (Eds.), An introduction to contemporary work psychology (pp. 171-195). Chichester, UK: Wiley Blackwell.

Singer, A., Gerber, M., \& Neuenschwander, M. P. (2013). Individuelle und soziale Bedingungen der beruflichen Sozialisation im Lehrbetrieb. In M. P. Neuenschwander (Ed.), Selektion in Schule und Arbeitsmarkt. Zürich: Rüegger Verlag.

Spector, P. E. (2006). Method variance in organizational research: Truth or urban legend? Organizational Research Methods, 9(2), 221-232.

Stalder, B. E. (2012). School-to-work transitions in apprenticeship-based VET systems: the Swiss approach. In S. Billett, G. Johnson, S. Thomas, C. Sim, S. Hay \& J. Ryan (Eds.), The Experience of School Transitions: Policies, Practice and Participants (pp. 123-139). Berlin: Springer.

Stalder, B. E., Meyer, T., \& Hupka-Brunner, S. (2011). TREE Project Documentation. In M. M. Bergman, S. Hupka-Brunner, A. Keller, T. Meyer \& B. E. Stalder (Eds.), Youth Transitions in Switzerland: Results 
from the TREE Panel Study (pp. 66-87). Zürich: Seismo.

Stalder, B. E., \& Nägele, C. (2011). Vocational education and training in Switzerland: Organisation, development and challenges for the future In M. M. Bergman, S. Hupka-Brunner, A. Keller, T. Meyer \& B. E. Stalder (Eds.), Youth transitions in Switzerland: Results from the TREE Panel Study (pp. 18-39). Zürich: Seismo.

Thoits, P. A. (2011). Mechanisms linking social ties and support to physical and mental health. Journal of Health and Social Behavior, 52(2), 145-161.

Vignoli, E. (2009). Inter-relationships among attachment to mother and father, selfesteem, and career indecision. Journal of Vocational Behavior, 75, 91-99.

Wang, J., \& Wang, X. (2012). Structural Equation Modeling. Applications using Mplus. Chichester: Wiley.

Watermann, R. (2000). Berufliche Wertorientierungen im Wandel. Eine Kohortenanalyse zur Dynamik arbeitsbezogener Einstellungen anhand von ALLBUS-Umfragedaten. Münster: Institut für sozialwissenschaftliche Forschung e.V. 